\title{
ENVIRONMENTAL TAXATION POLICY: THE CASE OF TAXES ON MOTOR FUELS IN THE EUROPEAN UNION
}

\author{
Dr Snežana Kaplanović* \\ University of Belgrade, Faculty of Transport and Traffic Engineering, Belgrade, Serbia \\ Dr Aleksandar Manojlović \\ University of Belgrade, Faculty of Transport and Traffic Engineering, Belgrade, Serbia
}

The first part of the paper researches and states the reasons why tax on motor fuels is considered one of the most important economic instruments in transport sector. In addition, the paper presents possible ways of differentiating motor fuels taxes and analyses the justification for imposing such taxes from the ecological viewpoint. The second part of the paper devotes special attention to the analysis of this economic instrument's application in the European Union Member States, as well as its place and role in the environmental protection policy.

Keywords: Motor fuels, Excise duty, Retail price, Environment

\section{INTRODUCTION}

Fuel tax is considered one of the most important economic instruments in the transport sector [11, 12]. The extent of its significance arises from its basic functions, which are:

- revenue generation,

- financing of transportation sector,

- efficiency improvement and

- internalisation of external costs.

Fuel tax generates significant state revenues available for reinvestment into the transport sector or to be used for general (non-transportation) consumption. Also, given that fuel is treated as any other type of goods, it should not be forgotten that the sale of fuel generates additional and, by no means insignificant, state revenues from value added tax (VAT). Low implementation costs and simple application are additional advantages of this instrument.

Aside from the fact that it represents an important source of state revenues, this economic instrument contributes to more effective use of transport infrastructure. Namely, fuel tax increases costs of vehicle use. Higher costs encourage a more effective use of vehicle by each individual driver, and therefore a more effective use of transport infrastructure in general.

This instrument is also a tool suitable for the implementation of a user pays principle given that to a great extend it poses a burden for the users of transport infrastructure in accordance with the degree of its use. In addition, it represents a good solution for internalization of external costs of $\mathrm{CO} 2$ emission and implementation of a polluter pays principle, given that the $\mathrm{CO} 2$ emission correlates with the quantity of fuel consumed.

Fuel tax influences the increase in fuel prices which is how it sends certain price-related signals which may drive consumers to act in an environmentally-responsible manner. Short-term effect of these price-related signals is reflected in lower fuel consumption due to smaller distances travelled and shift toward fuel efficient vehicles in households which have more than one vehicle. In the long run, reduced fuel consumption and smaller tax burden are achieved by purchasing fuel efficient vehicles and by decreasing the number of those with vehicles in their possession.

This instrument encourages the use of public transport, which has become very attractive to consumers due to lower prices. Also, it encourages the use of other environmentally friendly modes of transport (walking and cycling).

Fuel tax affects not only the demand side, e.g. consumers, but also the supply side. In fact, these taxes provide certain price incentives for manufacturers, driving them to invest in development and production of cleaner fuels and cleaner, more efficient vehicles in order to keep their position on the market and strengthen their competitive advantage. 
Also, it enables the country to reduce its oil dependency. The advantages for oil-importing countries are more than obvious. This tax can be of great benefit for the oil-exporting countries, too. Namely, by promoting and encouraging higher fuel efficacy the opportunity opens for the fuel which is not used domestically to be sold on a foreign market. In this manner significant revenue would be generated from export.

\section{DIFFERENTIATION OF THE TAXES ON MOTOR FUELS}

Fuel tax is differentiated pursuant to the following:

- emissions and

- fuel type.

Differentiation according to emissions is environmentally motivated. The purpose of this manner of tax differentiation is to impose a larger tax burden on high polluting fuels. Higher taxes on leaded than on unleaded petrol and lower taxes on low sulphur fuels than on fuels with high sulphur content, are just some of the examples. In many countries around the world this manner of taxation led to full phase-out of leaded petrol.

As opposed to the previous one, differentiation of fuel taxes based on fuel type is not always environmentally motivated. In case of favouring alternative over conventional fuels, it is evident that this manner of fuel taxation is based on ecological goals. The differentiation itself is made by exempting alternative fuels entirely from taxation or by their significantly lower taxation. In this manner, certain economic incentives are created encouraging consumers to opt for vehicles running on this type of fuel. However, fuel tax differentiation favouring diesel fuel over petrol has no ecological agenda. It results from the policy of protecting competitive advantage of certain sectors which are based on the use of diesel fuel and are particularly significant for economy of the given country. Agriculture is one of these sectors. In addition, in certain countries such differentiation is also used to protect public transportation. Along the same line, the reason for this manner of taxation in certain countries also lies in the fact that, when compared to petrol, diesel is more energy efficient and the same distance is travelled at lower fuel consumption. However, given that in this way diesel becomes relatively cheaper than petrol, the previous positive effects may be partly neutralized by the increased distances travelled by vehicles using diesel. Schip-

per and Fulton (2008) found that diesel cars are driven $60-100 \%$ more than petrol cars. This behavioural effect can be ascribed not only to self selection effects, but also partly to the rebound effect created by the better fuel economy of a diesel and the lower price of diesel fuel. Using typical elasticity to measure the driving rebound effect, Schipper and Fulton (2008) found a 5\% increase in annual driving on average, which might rise up to $12 \%$ depending on the country and assumed elasticity [13]. Given that diesel vehicles drive more kilometres then petrol, positive effects for the society on the whole may also be neutralized due to the fact that diesel is used by heavier vehicles (e.g. trucks, buses) which cause more damage to transport infrastructure.

\section{TAXES ON MOTOR FUELS IN THE EUROPEAN UNION}

In comparison with the rest of the world, European governments typically have the highest taxes on motor fuels. Three of the reasons for this are as follows:

- tax on motor fuel is an important source of state revenue,

- EU members are oil-importing countries and

- Kyoto obligations.

UNLEADED

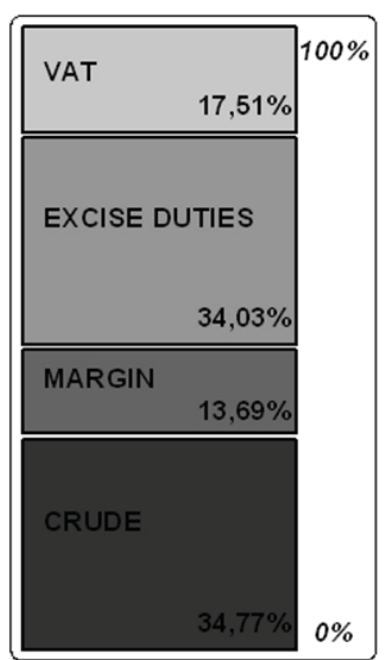

DIESEL

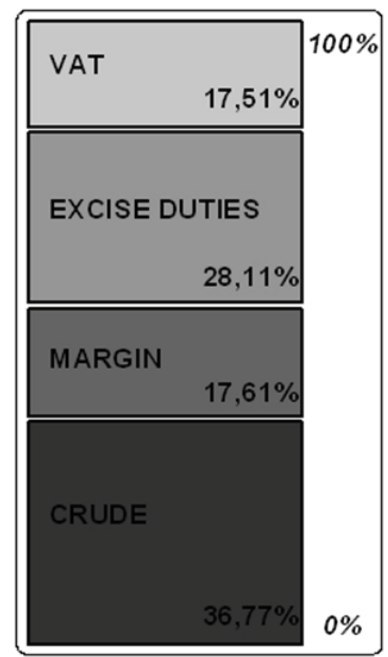

Figure 1: The components of the EU average retail price for 1 litre of fuel, February, 2013 [10]

The EU average retail price of a litre of unleaded petrol in February 2013 was $€ 1.544$, while, the EU average retail price of a litre of diesel was $€ 1.460$ [10]. The four main components of the retail price of a litre of motor fuel were: purchase price of one litre of crude, margin, excise duties 
and VAT. The excise duty component of the retail price of unleaded petrol averaged about $34 \%$ or $€ 0.525$ per one litre. For diesel this component is smaller and averaged about $28 \%$ or $€ 0.411$ per one litre. When VAT is included, tax represents around $52 \%$ of the retail price for unleaded petrol and around $46 \%$ for diesel (Figure 1) [10].

In addition to the countries of the European Union, a high level of taxes and fuel prices was noticeable in other European countries, as well as in Japan and Hong Kong. Among developed countries, the United States recorded the lowest fuel prices and taxes. In the United States, total taxes represent around $13 \%$ of the retail price for petrol and around $12 \%$ for diesel [09]. Significant subsidies on fuel, and thus lowest fuel prices are characteristic of oil-producing countries.

European motor fuel tax policy has significant environmental effects. According to the research by Sterner (2007), if all countries in the OECD had applied the price/tax policy pursued by the European counties with highest tax level, with long run price elasticity of -0.8 the whole OECD emissions of carbon from transport would have been $44 \%$ lower [14].

Table 1: Excise duties and retail prices in EU, February, 2013 (in € per one litre of fuel [10]

\begin{tabular}{|c|c|c|c|c|}
\hline \multirow{2}{*}{ COUNTRY } & \multicolumn{2}{|c|}{ UNLEADED } & \multicolumn{2}{|c|}{ DIESEL } \\
\hline & Excise duties & Retail price & Excise duties & Retail price \\
\hline Austria & $€ 0.482$ & $€ 1.422$ & $€ 0.397$ & $€ 1.365$ \\
\hline Belgium & $€ 0.614$ & $€ 1.714$ & $€ 0.428$ & $€ 1.531$ \\
\hline Bulgaria & $€ 0.363$ & $€ 1.342$ & $€ 0.322$ & $€ 1.352$ \\
\hline Cyprus & $€ 0.359$ & $€ 1.411$ & $€ 0.330$ & $€ 1.419$ \\
\hline Czech Republic & $€ 0.516$ & $€ 1.407$ & $€ 0.440$ & $€ 1.415$ \\
\hline Denmark & $€ 0.587$ & $€ 1.692$ & $€ 0.444$ & $€ 1.512$ \\
\hline Estonia & $€ 0.423$ & $€ 1.359$ & $€ 0.393$ & $€ 1.379$ \\
\hline Finland & $€ 0.650$ & $€ 1.638$ & $€ 0.470$ & $€ 1.543$ \\
\hline France & $€ 0.607$ & $€ 1.720$ & $€ 0.428$ & $€ 1.538$ \\
\hline Germany & $€ 0.654$ & $€ 1.611$ & $€ 0.470$ & $€ 1.447$ \\
\hline Greece & $€ 0.670$ & $€ 1.761$ & $€ 0.412$ & $€ 1.438$ \\
\hline Hungary & $€ 0.419$ & $€ 1.475$ & $€ 0.386$ & $€ 1.475$ \\
\hline Ireland & $€ 0.588$ & $€ 1.600$ & $€ 0.479$ & $€ 1.533$ \\
\hline Italy & $€ 0.704$ & $€ 1.845$ & $€ 0.593$ & $€ 1.755$ \\
\hline Latvia & $€ 0.408$ & $€ 1.382$ & $€ 0.330$ & $€ 1.353$ \\
\hline Lithuania & $€ 0.434$ & $€ 1.387$ & $€ 0.302$ & $€ 1.352$ \\
\hline Luxembourg & $€ 0.462$ & $€ 1.392$ & $€ 0.330$ & $€ 1.282$ \\
\hline Malta & $€ 0.469$ & $€ 1.470$ & $€ 0.382$ & $€ 1.380$ \\
\hline Netherlands & $€ 0.730$ & $€ 1.842$ & $€ 0.431$ & $€ 1.525$ \\
\hline Poland & $€ 0.380$ & $€ 1.308$ & $€ 0.330$ & $€ 1.310$ \\
\hline Portugal & $€ 0.584$ & $€ 1.700$ & $€ 0.366$ & $€ 1.502$ \\
\hline Romania & $€ 0.360$ & $€ 1.377$ & $€ 0.316$ & $€ 1.391$ \\
\hline Slovakia & $€ 0.515$ & $€ 1.495$ & $€ 0.386$ & $€ 1.420$ \\
\hline Slovenia & $€ 0.491$ & $€ 1.549$ & $€ 0.361$ & $€ 1.411$ \\
\hline Spain & $€ 0.425$ & $€ 1.449$ & $€ 0.331$ & $€ 1.387$ \\
\hline Sweden & $€ 0.620$ & $€ 1.744$ & $€ 0.554$ & $€ 1.732$ \\
\hline United Kingdom & $€ 0.674$ & $€ 1.593$ & $€ 0.674$ & $€ 1.676$ \\
\hline EU AVERAGE & $€ 0.525$ & $€ 1.544$ & $€ 0.411$ & $€ 1.460$ \\
\hline
\end{tabular}


In the implementation of the adopted motor fuel taxation policies, the most consistent countries are the pillars of economic development of the entire European Union. These are Germany and France. These are the only member states of the European Union which, despite the global economic crisis, kept unchanged amounts of excise duties for both types of fuel. On the other hand, in the countries most affected by the crisis, such as Greece, Italy and Cyprus, there was a significant increase in the tax burden. Compared to 2007, in 2013 in Greece, excise duties on diesel are about $50 \%$ higher, and those imposed on unleaded petrol are even $100 \%$ higher $[02,10]$. In the entire $\mathrm{EU}$, there is a notable trend of growth in excise duties on petrol and diesel fuels. This is a direct consequence of the need to increase state budget, as well as of the growing awareness of the harmful external effects created by burning fossil fuels. Otherwise, during the considered period, in most countries of the European Union the excise duties on diesel show higher growth than excise duties on petrol.

Fuel prices differ largely between the EU member states. The most important sources of these differences are excise duties and taxes in general (Table 1). In 2013, taking into account both unleaded petrol and diesel highest prices are registered in Italy and Sweden. In the same year, lowest fuel prices are registered in Poland and Bulgaria. Apart from these, lower fuel prices are also present in Romania and three Baltic countries, Estonia, Latvia and Lithuania [10]. Lower fuel prices in these countries are expected to an extent. They are a consequence of later accession and lower development degree compared to the leading economies of the European Union.

Luxembourg, which represents one of the most developed countries, also registers lower fuel prices, particularly diesel fuel prices. The reason lies in this country's strategy to attract consumers from neighbouring countries, as a country with lower fuel prices, and earn additional revenues in this way. Low fuel prices in Luxembourg result from low taxation. In this country the rise in revenues from fuel tourism gained importance in the period from 1998 to 2005 . There are two main reasons for this: fast internationalisation of road freight transport and introduction of Ecotax in Germany. In 2008, earnings from petrol and diesel sales to foreign vehicles amounted above $€ 1.500$ per Luxembourg inhabitant [05].
Lowering tax liabilities in small countries and countries with central position mainly aiming to achieve higher revenues from the sale of fuel to foreign drivers on domestic petrol stations, was one of the main reasons for setting minimal tax liabilities in the European Union (Table 2). In other respects, the tendency in the European Union is to even out the minimal amounts of excise duty on petrol and diesel by January 2015.

Table 2: Minimum levels of taxation applicable to motor fuels [03]

\begin{tabular}{|l|c|}
\hline MOTOR FUELS & $\begin{array}{c}\text { CURRENT MINIMUM } \\
\text { EXCISE RATES }\end{array}$ \\
\hline $\begin{array}{l}\text { Petrol } \\
\text { (in } € \text { per 1 000 I) }\end{array}$ & 421 \\
\hline $\begin{array}{l}\text { Unleaded petrol } \\
\text { (in } € \text { per 1 000 I) }\end{array}$ & 359 \\
\hline $\begin{array}{l}\text { Diesel } \\
\text { (in } € \text { per 1 000 I) }\end{array}$ & 330 \\
\hline $\begin{array}{l}\text { Kerosene } \\
\text { (in } € \text { per 1 000 I) }\end{array}$ & 330 \\
\hline $\begin{array}{l}\text { LPG } \\
\text { (in } € \text { per 1 000 kg) }\end{array}$ & 125 \\
\hline $\begin{array}{l}\text { Natural gas } \\
\text { (in } € \text { per gigajoule gross } \\
\text { calorific value) }\end{array}$ & 2.6 \\
\hline
\end{tabular}

Just like fuel prices, fuel taxes differ considerably across the European Union (Table 1). The Netherlands and Italy have the highest excise duty for unleaded petrol (above $€ 0.7$ per one litre). The United Kingdom, Greece, Germany, Finland, Belgium, Sweden and France also have high taxes on unleaded petrol (above $€ 0.6$ per one litre). On the other hand, the lowest taxes levied on unleaded petrol can be found in Poland, Bulgaria, Romania and Cyprus. In Cyprus excise tax rate is in line with the EU minimum excise tax rates (€ 0.359 per one litre). In Romania and Bulgaria it is only slightly above the minimum [10].

The United Kingdom has the highest excise duty for diesel (€ 0.674 per one litre). Italy is the runner-up, and far behind are Sweden, Ireland, Germany and Finland. Lithuania has the lowest excise duty on diesel. According to the Directive 2003/96/EC the current minimum level of taxation for diesel is $€ 0,330$ per one litre. Currently, in addition to Lithuania, Bulgaria and Romania are also below the minimum, whereas minimum level tax exists in Cyprus, Latvia, Luxembourg, and Poland [10]. 
By analyzing excise duties on motor fuels, it is clear that almost in all European Union member states there is a significant difference in the level of tax on petrol compared to diesel fuel. Namely, in most of these countries, diesel is preferred given that much higher excise duties are charged to petrol. The Netherlands, Greece and Portugal are the countries with most conspicuous favouring of diesel over unleaded petrol at the moment. In The Netherlands and Greece, tax burden on unleaded petrol is $60 \%$ higher than on diesel. At present, the difference in taxation of these two types of fuel is smallest in Estonia, Cyprus and Hungary (below 10\%), while in Bulgaria, Romania and Sweden this difference is only slightly above $10 \%$ [10].

Although due to political protection of certain economic sectors or modes of transport, most countries have lower diesel prices then prices of petrol, there are those with an entirely different practice. The United Kingdom is one of these countries. The reason for abandoning the policy of favouring diesel over petrol, among other reasons, is the serious concern present in this country regarding the negative effects of PM emissions produced mostly by the combustion of diesel fuel. For this reason, the British government has not only refused to implement the policy of favouring diesel, but it even applied higher taxes on this type of fuel frequently in the past twenty years. Today, these tax burdens are the same for both types of fuel $(0,674 €$ per one litre). Tax burdens in the United Kingdom were evened out in 2007 when taxes on both types of fuel amounted to $€ 0.713$ per one litre. Only a year earlier the policy of higher taxes on diesel then on unleaded petrol was in place. In that year 2006, tax on diesel amounted to $€ 0.693$ per one litre and was $€ 0.011$ higher than tax on unleaded petrol [01].

High prices of fuels and failure to favour diesel fuel result from the implementation of a policy based on environmental criteria. The fact that the United Kingdom is an island country represents extenuating circumstances for the implementation of the adopted taxation policy. As such, it does not have to worry whether the consumers will start buying cheap fuels in the neighbouring countries, or to fear the loss of revenues flowing into the state budget on these grounds.

Apart from the United Kingdom, there is another state from the Western Europe which does not implement the policy of lower taxes on diesel fuel. It is Switzerland, a country that is not an EU member. In this country, diesel fuel is subject to higher taxes then petrol so in this country diesel fuel is more expensive than petrol [05].

From the general aspect, in almost all the European Union Member States the policy is being implemented of taxing motor fuels favouring cleaner alternative motor fuels over the conventional ones (petrol and diesel). This also applies to biofuels. In a large number of member states, biofuels are either fully exempted from taxation or subject to far less tax compared to other types of fuel. The states which exempt biofuels from excise tax are Austria, Bulgaria, Estonia, Luxembourg, Malta and Portugal. The measures of partial excise tax exemption of biofuels are applied by the states such as Poland and Rumania in which this tax exemption amounts to 95\% [08]. Biofuels are used as an additive to petrol and diesel fuel. The policy of favouring ecologically cleaner fuels creates space for exemptions from paying excise duties or for recovery of excise duties for the part comprised of fuel of plant origin. These fiscal incentives can be found in many European countries. The basis for this kind of taxation is Directive 2003/96 EC, which provides Member States the option of applying a reduced rate of excise duty to pure or blended biofuels, when used either as motor or heating fuel.

In the EU, fiscal measures also encourage the use of other cleaner fuels and not just biofuels. This primarily refers to alternative fuels such as CNG (Compressed Natural Gas), LPG (Liquefied Petroleum Gas), hydrogen, etc. In most countries these fuels are subject to tax exemptions.

Incentives for environmentally responsible behaviour are discernible on the Union level as well. Under the Directive 2003/30/EC on the promotion of the use of biofuels or other renewable fuels for transport, EU established the goal of reaching a $5.75 \%$ share of renewable energy in the transport sector by 2010 [06]. Directive 2009/28/EC on the promotion of the use of energy from renewable sources, replaced Directive 2003/30/EC and set new target of minimum $10 \%$ for every member states by 2020 [07]. Fiscal measures can contribute significantly to the achievement of this goal.

In order to encourage more efficient use of energy in April 2011, the European Commission presented a proposal for a Council Directive 
amending Directive 2003/96/EC. According to the proposal, taxes on energy would be split into two components: CO2-related taxation and general energy consumption taxation [04]. Many European Union countries, Germany and Britain in the first place, criticized this proposal raising the concern that it would lead to higher prices of fuel and road transport. Hence, it remains to be seen when and if this proposal will be adopted.

\section{CONCLUSION}

The application of motor fuel taxes in the transport sector is widespread in the European Union. Although this type of tax is primarily fiscal in character, its environmental function is gradually coming to the forefront. Also, it is notable that there is a significant room for improvement. This in the first place implies higher degree of harmonization in the application of this instrument and its more extensive use in the struggle against climatic changes.

Nonetheless, it is indisputable that in the member states, as well as on the Union level, constant efforts are invested to use different economic instruments, including fuel taxes, as resources for achieving sustainable development. Since sustainable development is a global issue, the main aim is the revival of ecological awareness of people and sensibly greater engagement in the field of environmental policy in countries outside the European Union.

\section{ACKNOWLEDGEMENT}

The research work was supported by the Ministry of Education, Science and Technological Development of the Republic of Serbia (Grants No. 36010 and 36022).

\section{REFERENCES}

1) ACEA (2007) ACEA Tax Guide 2007 Introduction, http://www.acea.be/images/uploads/ tax/2007ACEATaxGuidedef Introduction. pdf, retrieved on January 7th, 2013.

2) ACEA (2008) ACEA Tax Guide 2008 Introduction, http://www.acea.be/images/uploads/ files/20080327_ACEA_Tax_Guide_2008_Introduction.pdf, retrieved on January 7 th, 2013.

3) Council of the European Union (2003) Council Directive 2003/96/EC of 27 October 2003 restructuring the Community framework for the taxation of energy products and electricity, Official Journal of the European Union L 283/51
4) European Commission (2011) Proposal for a Council Directive amending Directive 2003/96/EC restructuring the Community framework for the taxation of energy products and electricity

5) European Federation for Transport and Environment (2011) Fuelling oil demand: What happened to fuel taxation in Europe? T\&E, Belgium, Brussels

6) European Parliament and Council (2003) Directive 2003/30/EC of the European Parliament and of the Council of 8 may 2003 on the promotion of the use of biofuels or other renewable fuels for transport, Official Journal of the European Union L 123/42

7) European Parliament and Council (2009) Directive 2009/28/EC of the European Parliament and of the Council of 23 April 2009 on the promotion of the use of energy from renewable sources and amending and subsequently repealing Directives 2001/77/EC and 2003/30/EC, Official Journal of the European Union L140/16

8) http://www.cleanvehicle.eu, retrieved on January 27th, 2013.

9) http://www.eia.gov/petroleum/gasdiesel/, retrieved on February 19th, 2013.

10) http://www.energy.eu/\#, retrieved on February 19th, 2013.

11) Kaplanović, S., Ivković, I., Petrović, J. (2007) Porez na pogonska goriva u transportnom sektoru - instrument u funkciji zaštite životne sredine, Journal of Applied Engineering Science (Istraživanja i projektovanja za privredu), No. 16, pp. 39-46

12) Kaplanović, S., Petrović, J., Ivković, I. (2009) Ekonomski instrumenti u funkciji održivog razvoja drumskog saobraćaja, Journal of Applied Engineering Science (Istraživanja i projektovanja za privredu), No. 25 , pp. 17-22

13) Schipper, L., Fulton, L. (2008) Disappointed by diesel? The Impact of the Shift to Diesels in Europe through 2006, Research Reports. http:// metrostudies.berkeley.edu/pubs/reports/004 trb_diesel.pdf, retrieved on March 10th, 2013.

14) Sterner T. (2007) Fuel taxes: an important instrument for climate policy, Energy Policy 35(6), 3194-3202

Paper sent to revision: 19.03.2013.

Paper ready for publication: 16.05.2013. 